\title{
A derékfájás: mikor és mit tegyünk?
}

\author{
Illés S. Tamás dr. ${ }^{1,2}$ \\ 'Service d'Orthopédie et Traumatologie, Centre Hospitalier Universitaire - Brugmann, \\ Université Libre de Bruxelles, Bruxelles, Belgique \\ ${ }^{2}$ Department of Orthopedic Surgery and Traumatology, Odense University Hospital and Institute of Clinical \\ Research, University of Southern Denmark, Odense, Denmark
}

\begin{abstract}
A derékfájás világszerte az egyik legnagyobb népegészségügyi problémává vált. A szerző a jelenleg érvényes nemzetközi standardokra támaszkodva foglalja össze a derékfájás mindennapi ellátásában szükséges ismereteket. Az akut derékfájás ellátásában kiemeli a specifikus és nem specifikus derékfájás gyors és pontos diagnózisának, elkülönítésének szükségességét. Míg a specifikus esetekben a kiváltó okok specialisták által irányított ellátása szükséges, addig a nem specifikus esetekben fájdalomcsillapító kezelés, valamint korai és aktív mobilizálás a választandó terápiás eljárás. A kezelések elsődleges célja a tünetek hatékony csökkentése mellett megelőzni azok krónikussá válását. A krónikus derékfájdalom kezelésének célja a fájdalom hatékony csökkentése, a fizikai aktivitás folyamatos fenntartása, a tartós rokkantság megelőzése, valamint a munkaképesség visszaállítása. A fájdalomcsillapítók, a nem szteroid gyulladásgátlók és az izomlazítók csökkentik a fájdalmat, míg a multidiszciplináris kezelési programok, személyre szabott, irányított gyógytorna, kognitív viselkedésterápia, valamint rövid oktatási programok segítenek a funkció helyreállításában. Mütéti kezelés a konzervatív terápiás próbálkozások sikertelensége esetén csak a degeneratív kiváltó okok megszüntetésére irányulhat. Orv. Hetil., 2015, 156(33), 1315-1320.
\end{abstract}

Kulcsszavak: derékfájás, akut, krónikus, diagnózis, kezelés

\section{Low back pain: when and what to do}

The low back pain has become one of the greatest public health problems worldwide. The author based on the current international standards summarizes the knowledge necessary for every day treatment of low back pain. In acute low back pain the author underlines the necessity of the rapid, accurate diagnosis and separation for specific and nonspecific low back pain. In specific acute low back pain the treatment should focus on to eliminate the root causes. In non-specific cases pain killing treatment and early active mobilization is the choice for the therapeutic process. Beside analgesia, the primary goal of the treatment is to prevent becoming chronic the symptomatology. Objectives of the management of chronic low back pain are effective pain reduction, continuous maintainance of physical activity, prevention of permanent disability, and restoration of working ability. Analgesics, non steroid anti-inflammatory drugs, and muscle relaxants reduce pain, while multidisciplinary management programs, personalized and guided physiotherapy, cognitive behavioral therapy, as well as short training programs will help to restore function. Surgical treatment is only indicated in degenerative cases and only after the failure of conservative therapy.

Keywords: low back pain, acute, chronic, diagnosis, treatment

Illés, S. T. [Low back pain: when and what to do]. Orv. Hetil., 2015, 156(33), 1315-1320.

(Beérkezett: 2015. június 16.; elfogadva: 2015. július 2.)

\section{Rövidítések}

$\mathrm{CT}=$ komputertomográfia; $\mathrm{EMG}=$ elektromiográfia; MRI = mágneses rezonanciás vizsgálat; SPECT $=$ single photon emission computed tomography
A derékfájás sem nem betegség, sem nem diagnózis. A kifejezés az ágyéki gerincre lokalizált eltérő időtartamú, olyan gyakran előforduló fájdalmat jelöl, hogy a tü- 
net a külső vagy belső ingerekre adott paradigmává vált. Ennek ellenére, vagy talán éppen ennek következtében, a derékfájás kifejezetten gyakori egészségügyi probléma, amellyel a legtöbb ember szembesül életének valamely periódusában. A derékfájás az egyik leggyakoribb oka a normális napi tevékenység korlátozásának, és legfőbb oka a táppénznek. Az előfordulási adatok igen változóak: az átlagos prevalencia egy adott időpontban 18\%. A legalább egy hónapig tartó fájdalom előfordulása 31\%, egy évig a népesség 38\%-a érez fájdalmat, míg az egész életen át tartó repetitív fájdalom előfordulása 39\%. Az előfordulás magasabb a nők körében $(35 \%)$, szemben a férfiakkal (29\%). A derékfájás leggyakrabban a 40-80 éves korosztályban fordul elő. A 3 hónapnál hosszabb ideig fennálló fájdalom aránya $20 \%[1,2]$.

A derékfájás definíciója - fájdalom, diszkomfort vagy kellemetlen érzés a bordaívek alatt az ágyéki gerincre, valamint a farpofákra lokalizáltan, amelyhez kisugárzó fájdalom társulhat egyik vagy mindkét alsó végtagba nagyon bizonytalan, hiszen a tünetegyüttes pontosítására több elemet is hozzákapcsoltak a fenti definícióhoz, mint például a fájdalom időtartama és intenzitása, orvosi vizit, kezelés vagy táppénz szükségessége [3].

A derékfájás osztályozható a panaszok hossza alapján is: akut a derékfájás, ha kevesebb mint hat hétig áll fenn, míg krónikus derékfájással állunk szemben, ha a tünetek 3 hónapnál hosszabb ideig vannak jelen.

\section{Akut derékfájás}

Az akut derékfájás diagnózisának elsősorban a specifikus és nem specifikus derékfájás elkülönítésére kell fokuszálnia. Specifikus deréktáji fájdalomról definíció szerint akkor beszélünk, ha a fájdalom hátterében igazoltan vagy feltételezhetően valamilyen ismert patofiziológiai mechanizmus - mint például gyöki kompresszió, cauda equina szindróma, strukturális deformitás, trauma, törés, daganat, fertőzés vagy valamilyen gyulladásos betegség - áll. Ezzel ellentétben jelenleg nincs megbízható és érvényes klasszifikáció az akut nem specifikus derékfájás osztályozására. Ezt a diagnózist csak az ismert okok egyértelmű kizárása után tudjuk felállítani.

\section{Diagnózis}

A klinikai gyakorlatban a triage-nak az úgynevezett „vörös zászlók” azonosítására kell összpontosítania, amely segít kizárni az ágyéki fájdalom hátterében meghúzódó speciális betegségeket [4]. Vörös zászlók közé tartozik például a beteg 20 és 55 év közötti életkora, a fájdalom nem mechanikus jellege, amely független a napszaktól vagy tevékenységtől, jelentős trauma, tumor jelenléte az anamnézisben, hosszan tartó szteroidkezelés, megmagyarázhatatlan fogyás, és hirtelen megjelenő vagy súlyosbodó neurológiai tünetek. A fizikális vizsgálat hivatott megerősíteni vagy kizárni a potenciálisan súlyos betegségeket. A fizikális vizsgálat alapvető elemei mellett meg kell határozni az ágyéki gerinc mozgásterjedelmét, valamint a neuromuscularis státust, különös tekintettel az esetleges érzéskiesésekre, valamint az izomerő meghatározására. A Lasègue-jel az egyik diagnosztikai szabványnak tekinthető, amelyet széles körben alkalmaznak. Látszólag könnyen kivitelezhető és értelmezhető, megbízhatósága azonban csak pontos kivitelezés esetén értékelhető [5].

Specifikus akut derékfájás feltételezése esetén, annak bizonyítására képalkotó vizsgálatok végezhetők. Első lépésben ágyéki gerincröntgen, míg neurológiai érintettség gyanújakor MRI az első ajánlott eljárás. CT végzése csak csontosodási zavar igazolása esetén elengedhetetlen. Nem specifikus derékfájás fennálltakor az 50 évesnél fiatalabb betegeknél a kezelés eredményességén a diagnosztikus képalkotó vizsgálatok elvégzése sem javít [6]. Így fejlett képalkotó eljárásokat csak azoknál a betegeknél kell feltétlenül elvégezni, akiknél a panaszok hátterében valamilyen ismert ok erósen gyanítható, vagy akiknél várhatóan mútéti kezelés jön szóba [7].

\section{Kezelés}

A diagnosztikai triage eredményének függvényében valószínúleg cauda equina szindróma van jelen, amikor a beteg hólyagdiszfunkcióról számol be, amely lehet inkontinencia, alkalmankénti túlcsordulás, záróizomdiszfunkció vagy vizeletretenció, amelyhez az összes érzésfajta hiánya, gyakran lovaglónadrág alakzatban, progrediáló alsó végtagi izomgyengeség és járászavar társulhat. A szindróma gyanúja esetén a beteg azonnal sebészeti ellátóintézménybe irányítandó, ugyanis akut lumbago esetén az egyetlen abszolút indikációt sebészeti beavatkozásra a cauda equina szindróma jelenti [8].

Egyéb specifikusnak ítélt akut derékfájás esetén a további célzott ellátás biztosítása érdekében a betegeket a vizsgálati eredmények függvényében kell specialistához irányítani.

Nem specifikus derékfájás kezelése esetén azonban a legfontosabb teendő a betegek megfelelő tájékoztatása, megnyugtatása, hogy betegsége nem súlyos, általában megfelelő kezelés és életmód mellett leginkább gyors felépülés várható. Az akut fájdalom csökkentésére gyógyszeres terápia bevezetése javasolt lehetőleg rövid intervallumra, ha szükséges rendszeres időközönként ismételve. Az első választandó gyógyszer a paracetamol. Ennek hatástalansága esetén második körben nem szteroid gyulladásgátlót kell alkalmazni. Megfontolható rövid ideig tartó izomlazító kezelés vagy önmagában, vagy nem szteroid gyulladásgátlóval kombinálva, amennyiben paracetamol és/vagy nem szteroid gyulladásgátló alkalmazásával nem sikerült csökkenteni a fájdalmat. $\mathrm{Az}$ izomlazítók hatásossága egyértelmúen bizonyított ugyan, azonban fokozottan kell figyelni az esetleges mellékhatásokra, mint például aluszékonyság [9].

Egyértelmúen bizonyítást nyert, hogy a passzív kezelési módokat - mint ágynyugalom, elektroterápia, ultra- 
hang, lézer- vagy akupunktúrás kezelés - feltétlenül kerülni kell. Ugyanez vonatkozik akut derékfájás esetén az epiduralis szteroidinjekciók adására is. Végül nincs bizonyíték, amely azt mutatja, hogy egyéb beavatkozások (például: ágyéki füzőkezelés, nyújtás vagy masszázs) hatásosak az akut deréktáji fájdalom kezelésében [10].

A betegeket feltétlenül ösztönözni kell arra, hogy a gerincfájdalom ellenére maradjanak aktívak, és továbbra is végezzék el szokásos napi tevékenységüket, ideértve a munkavégzést is. Az aktív megközelítés a legjobb kezelési lehetôség az akut derékfájás terápiájában [5].

A nem specifikus akut derékfájás esetében a legnagyobb veszélyt a tünetek krónikussá válása jelenti.

Az akut derékfájás átmenete krónikus derékfájásba egy bonyolult folyamat következménye, amelyben - a legújabb bizonyítékok szerint - számos egyéni, pszichoszociális és a munkahelyi körülményekhez kapcsolódó tényező is szerepet játszik. A prognosztikai faktorok pontos meghatározása elengedhetetlen, amely segít elkülöníteni a kedvezőtlen prognózisú eseteket. A krónikus derékfájás által veszélyeztetett betegek kiszúrése rendkívül fontos a hosszú távú munkaképesség-csökkenés és rokkantság megelőzése céljából. A korai felismerés lehetővé teszi egy relatíve gyors kezelési terv felállítását és a szükséges beavatkozások elvégzését. A gyorsaságra azért van szükség, mert minél hosszab ideig áll fenn a fájdalom és a mozgáskorlátozottság, annál kisebb az esély a derékfájás sikeres kezelésére [11].

A krónikus derékfájás kialakulásának első figyelmeztető jele lehet az akut derékfájás során észlelt igen jelentős fájdalom és mozgáskorlátozottság, azaz eltúlzott funkcionális fogyatékosság jelenléte. Az egyéni tényezők közül az idősebb életkor, az alacsony iskolai végzettség, a rossz általános egészségi állapot és a fizikai erőnlét, a hát- és a hasizmok gyengesége, elégtelen volta, valamint az elhízás emelhető ki, amelyek mellett a legfontosabb figyelemfelkeltő jel a dohányzás! Nagyon fontos az esetleges pszichológiai faktorok, mint emelkedett pszichoszociális stressz, szorongás, depresszió, negativisztikus hangulat és érzelmek, alacsony fájdalomküszöb, szomatizációra való hajlam, szegényes kognitív funkciók felismerése. A munkahelyi körülmények közül kiemelkedik a nagy, monoton fizikai terhelés, a folyamatos állás, az ismétlődó hajlító és csavaró mozgások, a teljes test vibrációja, amelyet súlyosbíthat a magas munkahelyi követelményszint, valamint a szegényes munkakapcsolatok. Az ágyéki fájdalom krónikussá válásában a betegséggel összefüggésben esetleges pénzügyi kompenzáció reménye is szerepet játszhat [9].

\section{Krónikus derékfájás}

Krónikus derékfájásról beszélünk, ha a legalább 3 hónapja fennálló fájdalom az ágyéki gerincre lokalizálódik, amelyhez néha egyik vagy mindkét alsó végtagba kisugárzó akut fájdalom társulhat. A Francia Gerincsebészeti Társaság 2014. novemberben elfogadott ajánlásában a krónikus derékfájás klasszifikációjára a következő besorolást javasolja:

- Nem degeneratív derékfájás - az akut specifikus derékfájás krónikus megfelelője -, amely általában gyöki kompresszióra, traumára, tumorra, osteoporoticus törésre, gyulladásra vagy egyéb gyulladásos megbetegedésre (rheumatoid arthritis, spondylitis ankylopoetica stb.) vezethető vissza.

- Degeneratív derékfájás: amely általában intervertebralis discus vagy kisízületi rendellenesség következtében alakul ki.

- Pszichogén derékfájás.

\section{Diagnózis}

A krónikus derékfájás diagnózisának első lépése meggyőződni arról, hogy a probléma valóban mozgásszervi eredetú-e. Ki kell zárni minden, gerincen kívüli patológia, elsősorban urogenitalis vagy nőgyógyászati betegség lehetőségét. A következő lépés a nem degeneratív gerincpatológia kizárása. Ezek közé tartoznak az akut specifikus gerincfájdalom során már felsorolt úgynevezett „vörös zászlós” elváltozások, amelyek azonban 3 hónapnál hosszabb ideig is okozhatnak fájdalmat. Egyes szerzők ebbe a csoportba ajánlják sorolni a discusherniák következtében kialakuló derékfájdalmakat, amelyek nem tartoznak ugyan az abszolút mütéti indikáció csoportjába, de a konzervatív kezelés ellenére perzisztáló fájdalom lehet jelen. A discushernián kívül ebbe a csoportba tartozó állapotok azonban kifejezetten ritkák [12].

Krónikus degeneratív derékfájásra kell gondolni makacs ágyéki fájdalom mellett észlelt szegényes klinikai jelek esetén. Ennek hátterében gyakran degeneratív kisízületi vagy discuselváltozások állnak. Fájdalmat generálhat többek között a csigolya-zárólemezek degenerációja (Modic-jelek), kisízületek arthrosisa. Discusdegeneráció következménye lehet a lumbalis gerinc szegmentális instabilitása, a repetitív hipermobilitás következtében kialakuló degeneratív retrolisthesis vagy antelisthesis is. Több discust érintő degeneráció esetén a gerincgörbület lokális megváltozása következhet be, amely súlyos esetben degeneratív scoliosist is eredményezhet [13].

Gyöki kompresszió és/vagy degeneratív eredetű derékfájás gyanújának igazolására képalkotó vizsgálatokat kell végezni. Első lépésben ágyéki gerincröntgen végzendő. Gyöki érintettség vagy discusdegeneráció feltételezése esetén MRI végzése, míg gerincdeformitások fennállta esetén kétirányú teljes gerincröntgen végzése is elengedhetetlen. CT-vizsgálatra csak pars interarticularis lysis, valamint primer vagy szekunder canalis spinalis stenosis gyanújának megerősítésére van szükség. Az EMG-vizsgálatok hasznosságáról krónikus derékfájás diagnózisa esetén megoszlanak a vélemények. Csontdenzitometriát vagy SPECT-vizsgálatot csak ágyéki fúziós mútéteket követően, a csontos fúzió minőségének megítélésére érdemes elvégezni [14]. 
Pszichoszomatikus problémák talaján kialakuló derékfájások alkotják a krónikus derékfájás legnagyobb csoportját. Ez a diagnózis makacs ágyéki fájdalom esetén, szegényes klinikai kép, valamint eredménytelen vagy szegényes képalkotó vizsgálatok után állítható fel.

Feltétlenül azonosítani és „narancs zászló”-val kell jellemezni olyan meglévő súlyos pszichopatológiai problémákat, mint a poszttraumás stressz, a személyiségi zavarok vagy a depresszió, amelyek megkövetelik speciális szakember vizsgálatát és kezelését.

„Sárga zászlóval” jellemezhetők az egyéb pszichológiai tényezők, mint az emelkedett pszichoszociális stressz, amely magába foglalja a félelmet a fájdalomtól vagy sérülésektől, a meggyőződést a felépülés sikertelenségében, amelyet a reménytelenség, az elkeseredés, a negativisztikus hangulat is befolyásol. Jellemző még a szorongás, az alacsony fájdalomküszöb, a szomatizációra való hajlam és a szegényes kognitív funkciók jelenléte is.

„Kék zászlóval” illethetook a munkahelyi körülmények, mint a hosszú, monoton fizikai terhelés, a folyamatos állás, a hajlító és csavaró mozgások, a teljes test vibrációja, amelyet súlyosbíthat a magas munkahelyi követelményszint, valamint a szegényes munkakapcsolatok.

„Fekete zászló” a minősítése a munkáltatók negatív véleményének, a túlzottan aggódó családnak, valamint a betegséggel összefüggésben remélt esetleges pénzügyi kompenzációnak, a tartós rokkantság elérése reményének [15].

A krónikus derékfájást több szempont egybevetésével kell értékelni, amelyek a fájdalom, az ágyéki gerincfunkció, az általános jóllét, a társadalmi és foglalkozási fogyatékosság, valamint a beteg megelégedettsége. Előfordul, hogy egyes esetekben egy-két erősen pozitív tényezőre vezethető vissza a krónikus derékfájás, míg más esetekben több tényező alacsony szintű, de együttes előfordulása okozza a tüneteket. Mivel a kiváltó tényezők közül több is potenciálisan módosítható, az okok precíz azonosítása elengedhetetlen. Számos kérdőívet dolgoztak ki azzal a céllal, hogy megkönnyítsék az egyes eltérő szempontok felmérését és értékelését a krónikus derékfájás esetén [16]. Az egyik legelfogadottab a „STarT Back Screening Tool", amely azon páciensek kiszürésére és csoportosítására készült, akik potenciálisan megváltoztatható prognosztikai faktorokkal bírnak [17].

\section{Kezelés}

A krónikus derékfájás kezelésére - ellentétben az akut derékfájással - nagyon kevés széles körben elfogadott ajánlás létezik, tekintettel arra, hogy a krónikus derékfájás nem egy jól körülhatárolható klinikai entitás. A betegek hosszabb-rövidebb panaszos periódus után a fájdalom, a funkciókiesés és a rokkantság nagyon különböző szakaszaiban és szintjein fordulnak orvoshoz. Ezért is elengedhetetlen a prognosztikai faktorok egyénre szabott nagyon pontos értékelése a kezelés megkezdése elött.
A krónikus derékfájás esetében mind a diagnosztikus megközelítésben, mind a terápia hatásosságának szempontjából nagyon korlátozott a pozitív bizonyítékok száma. A legtöbb ajánlott terápiás eljárás hatása is meglehetősen szerény.

Az elváltozás multidimenzionális jellegéből következően nincs egyetlen olyan beavatkozás sem, amely hatásos a hosszabb ideje fennálló, jelentős fogyatékosságot okozó krónikus derékfájás összes aspektusának kezelésében $[14,18]$.

A krónikus derékfájás terápiájának egyidejúleg kell fokuszálnia a fájdalom csökkentésére, az ágyéki gerinc funkcióinak helyreállítására, a beteg pszichológiai támogatására, valamint munkahelyi rehabilitációjára.

\section{A fájdalom kezelése}

Első lépésben rövid ideig adott paracetamol vagy nem szteriod gyulladáscsökkentők ajánlhatók annak ellenére, hogy nincs egyértelmú bizonyíték fájdalomcsillapító hatásukra ebben az indikációban.

Hatástalanság esetén gyenge opioidok kombinálhatók a fenti gyógyszerekkel, esetleg izomlazítókkal kiegészítve.

Erős opioidokat csak eseti alapon, a kontraindikációk figyelembevételével lehet alkalmazni. Csak azoknál a betegeknél ajánlható, ahol a pszichoszomatikus eredet egyértelmű kizárása után minden másfajta kezelés hatástalan maradt. A kezelés időtartamát korlátozni kell (maximum 2 hét), míg a gyógyszerek elhagyását a dózis fokozatos csökkentésével kell elérni. Triciklusos antidepresszánsok, epilepszia elleni gyógyszerek használata nem ajánlott, csakúgy, mint a szisztémás kortikoszteroidok használata. Ugyancsak nem ajánlottak - egyértelmú evidenciák hiányában - a különféle fizikai/kémiai kezelések (meleg/ hideg pakolások, lézer, ultrahang, rövidhullám, interferencia, masszázs, nyújtás, füzőkezelés). Az epiduralis kortikoszteroidok vagy a kisízületi blokád eredményességéről sincs egyértelműen pozitív bizonyítékunk. Tekintettel azonban az igen eltérő egyéni reakciókra, ezek a kezelések rövid távú fájdalomcsillapításként - individuális mérlegelés után - ajánlhatók [8].

\section{A funkció helyreállítása}

Az irányított és felügyelt gyógytorna, a gerinciskola pozitív hatása egyértelmúen bizonyított a krónikus lumbago kezelésében, így ezek végzése erősen ajánlott. Lehet egyénileg vagy csoportterápia során, esetleg multidiszciplináris programok keretében végezni. A legfontosabb cél a személyre szabott tevékenységek és gyakorlatok kiválasztása az ágyéki merevség megelőzése, valamint az izommúködés és a fizikális kondíció megőrzése érdekében. A speciális gyakorlatsorozatok (például McKenzie) előnye nem bizonyított.

\section{Lélektani támogatás}

A krónikus derékfájás kezelésében kognitív viselkedésterápia, rövid oktatási programok és multidiszciplináris 
(bio-pszicho-szociális) kezelési programok mindegyike javasolható. A kognitív viselkedésterápiák jó hatással vannak nemcsak a fájdalom intenzitására, hanem segítenek a betegeknek megtanulni irányítani és kezelni a fájdalmat. A kezelés során szükséges a pozitív hozzáállás és stratégia kialakítása, elősegítendő a betegeknek elfogadni a gerinc állapotát, megtanulni együtt élni a mindennapi fájdalommal, amely valószínúleg soha nem tûnik el teljesen. Az oktatási programok célja egyfajta terápiás autonómia megszerzése a gerincbetegségek relatív jobb megismerése révén.

A multidiszciplináris kezelési programban alkalmazható csoportfoglalkozások, tanácsadások, a testmozgás és a pszichológiai segítség arra irányul, hogy a betegek minél tovább aktívak maradjanak, vagy minél gyorsabban viszszanyerjék mindennapi aktivitásukat [16].

\section{Munkahelyi rehabilitáció}

A legfontosabb feladat a krónikus derékfájásban szenvedő betegek szakmai rehabilitációja. Ez a munkavállaló, a háziorvos, a kezelőorvos, valamint az üzemorvos szoros kollaborációját feltételezi. Mihelyt a munkaképességcsökkenés előre jelezhető vagy kiszámítható, a szükséges intézkedések (ergonomikus munkahelyi elrendezés, könnyített munkavégzés, munkahelyváltás stb.) mielőbbi megtétele céljából konzultációt és/vagy felülvizsgálatot kell kezdeményezni [14].

\section{Mütéti kezelés}

Krónikus derékfájás esetén a mütét csak az intervertebralis discusok degeneratív elváltozásai talaján kialakult, illetve azt kísérő esetekben javallt.

Pszichogén eredetű derékfájás esetén mütétet végezni kontraindikált, mivel az tovább rontja a beteg gyógyulásának esélyeit.

A mütéti kezelés eredmenyességérôl alkotott vélemények ellentmondásosak. Számos szerző nem talált különbséget a konzervatív kezelés és a fúziós mütétek eredményessége között, ezért általában a műtétek elvetését ajánlják [19]. A valóságban a konzervatív, valamint a mútéti kezelés összehasonlítása mesterséges. A klinikai gyakorlatban a konzervatív kezelés és a mútéti beavatkozások nem versenyképes kezelések, ugyanis nem végezzük őket párhuzamosan. Mütétet jellemzően csak a konzervatív kezelés kudarca után vagy elégtelen eredménye esetén fontolunk meg. A megfelelő indikációval elvégzett ágyéki fúziós mütétek általában jelentős javulást eredményeznek mind a fájdalom, mind a gerinc funkciójának tekintetében [20]. A gerincsebészeti fúziós eljárások eredményezte klinikai javulás összemérhető egyéb széles körben elfogadott ortopédiai eljárásokkal, mint például a térd- vagy csípőprotézis-mütétek, valamint egyéb gerincmútétekkel, mint a spinalis stenosis miatt végzett dekompressziós mütét [21]. Ez azonban csak a degeneratív elváltozások talaján kialakult krónikus derékfájás esetében van így.
Összefoglalva: A derékfájás igen összetett patomechanizmus eredménye. Tekintettel a jelentősen eltérő egyéni jellegzetességekre és reakciókra, a kezelések során nem mindig lehet egyértelmú sablonokat alkalmazni. Azok a kezelések, amelyek ugyan nem rendelkeznek széleskörűen elfogadott bizonyítékokkal, individuális esetekben kifejezetten hatékonyak lehetnek. Annak eldöntésében, hogy mely esetben milyen kezelések lesznek a leginkább célravezetők, a betegek és környezetük pontos ismerete elengedhetetlen. Ennek megfelelően a derékfájás sikeres kezelésének irányításában a legjobb helyzetben a betegeket és környezetüket leginkább ismerő háziorvosok vannak.

Anyagi támogatás: A szerző a közlemény megírása és a kapcsolódó kutatómunka során anyagi támogatásban nem részesült.

A szerző a cikk végleges változatát elolvasta és jóváhagyta.

Érdekeltségek: A szerzőnek nincsenek érdekeltségei.

\section{Irodalom}

[1] Hoy, D., Bain, C., Williams, G., et al.: A systematic review of the global prevalence of law back pain. Arthritis Rheum., 2012, 64(6), 2028-2037.

[2] Ferenc, M., Varga, P. P.: Low back pain. [Derékfájás.] Háziorvos Továbbképző Szemle, 2011, 16(8), 398-404. [Hungarian]

[3] Ozguler, A., Leclerc, A., Landre, M. F., et al.: Individual and occupational determinants of low back pain according to various definitions of low back pain. J. Epidemiol. Community Health, $2000,54(3), 215-220$

[4] Tamási, L.: Low back pain. [Derékfájás.] Háziorvos Továbbképző Szemle, 2012, 17(7), 379-382. [Hungarian]

[5] Van Tulder, M., Becker, A., Bekkering, T., et al.: European guidelines for the management of acute nonspecific low back pain in primary care. Eur. Spine J., 2006, 15(Suppl. 2), S169-S191.

[6] Bálint, G.: The modern principles of diagnosis and management of the low back pain. [A derékfájás diagnosztikájának és kezelésének modern elvei.] Lege Artis Medicinae, 2011, 21(5), 329335. [Hungarian]

[7] Jarvik, J. G., Deyo, R. A.: Diagnostic evaluation of low back pain with emphasis on imaging. Ann. Intern. Med., 2002, 137(7), 586-597.

[8] Koes, B. W., van Tulder, M., Lin, C. W., et al.: An updated overview of clinical guidelines for the management of non-specific low back pain in primary care. Eur. Spine J., 2010, 19(12), 2075-2094.

[9] Koes, B. W., van Tulder, M. W., Thomas, S.: Diagnosis and treatment of low back pain. BMJ, 2006, 332(7555), 1430-1434.

[10] Van Tulder, M. W., Koes, B. W.: Low Back Pain: Acute. Clinical Evidence. BMJ Publishing Group, London, 2006.

[11] Hayden, J. A., Dunn, K. M., van der Windt, D. A., et al.: What is the prognosis of back pain? Best Pract. Res. Clin. Rheumatol., 2010, 24(2), 167-179.

[12] Carragee, E. J., Hannibal, M.: Diagnostic evaluation of low back pain. Orthop. Clin. North Am., 2004, 35(1), 7-16.

[13] Modic, M. T., Ross, J. S.: Lumbar degenerative disk disease. Radiology, 2007, 245(1), 43-61. 
[14] Airaksinen, O., Brox, J. I., Cedraschi, C., et al.: European guidelines for the management of chronic nonspecific low back pain. Eur. Spine J., 2006, 15(Suppl. 2), S192-S300.

[15] Nicholas, M. K., Linton, S. J., Watson, P. J., et al.: Early identification and management of psychological risk factors ("yellow flags") in patients with low back pain. Phys. Ther., 2011, 91(5), 737-753.

[16] Rozenberg, S., Foltz, V., Fautrel, B.: Treatment strategy for chronic low back pain. Joint Bone Spine, 2012, 79(6), 555-559.

[17] Hill, J. C., Whitehurst, D. G., Lewis, M., et al.: Comparison of stratified primary care management for low back pain with current best practice (STarT Back): a randomised controlled trial. Lancet, 2011, 378(9802), 1560-1571.

[18] Apáthy, Á.: Low back pain pitfalls. [Derékfájás buktatókkal.] Magyar Családorvosok Lapja, 2011, 4, 13-16. [Hungarian]

[19] Mirza, S. K., Deyo, R. A.: Systematic review of randomized trials comparing lumbar fusion surgery to nonoperative care for treatment of chronic back pain. Spine, 2007, 32(7), 816-823.
[20] Phillips, F. M., Slosar, P. J., Youssef, J. A., et al.: Lumbar spine fusion for chronic low back pain due to degenerative disc disease: a systematic review. Spine, 2013, 38(7), E409-E422.

[21] Hansson, T., Hansson, E., Malchan, H.: Utility of spine surgery: a comparison of common elective orthopaedic surgical procedures. Spine, 2008, 33(25), 2819-2830.

(Prof. Dr. Tamás S. Illés, Service d'Orthopédie et Traumatologie, CHU - Brugmann, ULB Place Van Gehuchten 4, 1020 Bruxelles, Belgique e-mail: tamas.illes@chu-brugmann.be tamas.illes@ulb.ac.be)

\section{ROMHÁNYI ORVOSTALÁLKOZÓ \\ Lelkigyakorlat (manreza) orvosoknak \\ Szár, Római katolikus templom \\ 2015. augusztus 29.}

9:00 Szentmise

10:00 Üdvözlések: Moharos Péter polgármester

Prof. Dr. Kellermayer Miklós: Személy voltunk titka Tolsztoj és József Attila szerint

Prof. Dr. Németh Péter: Rövid filmösszeállitás Romhányi György professzorról

10:30 Beer Miklós váci megyéspüspök: Az értelmiség magatartási és életviteli példája az ifjúság felé

11:00 Nacsinák Gergely ortodox teológus: Az emberi személy egysége a keleti keresztény hagyományban

11:30 Petrás Mária népdalénekes, keramikus és Döbrentei Kornél, író, költö, újságíró:

Mit jelent a hüség a nemzethez, a hazához és az emberiséghez a XXI. században

\section{Romhányi emléktábla megkoszorúzása - Ebédszünet}

14:00 Dr. Tóth Tihamér, Hodásziné Dr. Tóth Edit: Véletlen? Gondviselés? Szükségszerüség?

14:30 Prof. Dr. Nagy Judit: A vese a legelegánsabb szerv (vesebetegségekröl Romhányi György szellemében)

15:00 Prof. Dr. Nyárády József: Játék és gyötrelem a traumatológiában

15:30 Prof. Dr. Molnár Péter: Miként élhet tovább a Romhányi-Endes szemlélet az „Z+” generáció oktatásában?

Moderátor: Prof. Dr. Szelényi Zoltán

\section{Genzwein Ferenc sírjának megkoszorúzása}

Részvételi szándék augusztus 20-ig jelezhetö:

Koltayné Bartha Magda 06-70/350-2062 telefonszámán naponta 14-18 óra között

e-mail: baratikor.saar@gmail.com 